Lauzon Rebecca (Orcid ID: 0000-0002-2230-6671)

Murray A Brad (Orcid ID: 0000-0002-2484-9151)

Ells Kenneth, D (Orcid ID: 0000-0003-4047-5521)

Lazarus Eli, D. (Orcid ID: 0000-0003-2404-9661)

\title{
Correlation between shoreline change and planform curvature on wave-dominated, sandy coasts
}

Lauzon, R. ${ }^{1}$, Murray, A. B. ${ }^{1 *}$, Cheng, S. ${ }^{1}$, Liu, J. ${ }^{1}$, Ells, K. D. ${ }^{2}$, and Lazarus, E. D. ${ }^{3}$

${ }^{1}$ Nicholas School of the Environment, Duke University, Durham, NC, USA

${ }^{2}$ Department of Physics and Physical Oceanography, University of North Carolina Wilmington, Wilmington, NC, USA

${ }^{3}$ Environmental Dynamics Lab, School of Geography \& Environmental Science, University of Southampton, Southampton, SO17 1BJ, UK

Corresponding Author: abmurray@duke.edu

Key Point \#1: Shoreline change on sandy, wave-dominated barrier islands is partially explained by shoreline smoothing from alongshore transport gradients.

Key Point \#2: Where shoreline stabilization is not prevalent, shoreline curvature can explain a significant amount of the shoreline change signal.

Key Point \#3: Correlation strength varies regionally with wave climate in ways that are consistent with theoretical and model predictions.

\begin{abstract}
Low-lying, wave-dominated, sandy coastlines can exhibit high rates of shoreline change that may impact coastal infrastructure, habitation, recreation, and economy. Efforts to understand and quantify controls on shoreline change typically examine factors such as sea-level rise; anthropogenic modifications; geologic substrate, nearshore bathymetry, and regional geography; and sediment grain size. The role of shoreline planform curvature, however, tends to be overlooked. Theoretical and numerical-model considerations indicate that incident offshore waves interacting with even subtle shoreline curvature can drive gradients in net alongshore sediment flux that can cause significant erosion or accretion. However, these predictions or assumptions have not often been tested against observations, especially over large spatial and temporal scales. Here, we examined the correlation between shoreline curvature and shoreline-change rates for spatially extended segments of the U.S. Atlantic and Gulf Coasts ( $1700 \mathrm{~km}$ total). Where shoreline stabilization (nourishment or hard structures) does not dominate the shoreline-change signal, we find a significant negative correlation between shoreline curvature and shoreline-change rates (i.e. convex-seaward curvature
\end{abstract}

This article has been accepted for publication and undergone full peer review but has not been through the copyediting, typesetting, pagination and proofreading process which may lead to differences between this version and the Version of Record. Please cite this article as doi: 10.1029/2019JF005043 
(promontories) is associated with shoreline erosion, and concave-seaward curvature (embayments) with accretion) at spatial scales of 1-5 km alongshore and time scales of decades to centuries. This indicates that shoreline changes observed in these reaches can be explained in part by gradients in alongshore sediment flux acting to smooth spatial variations in shoreline curvature. Our results suggest that shoreline curvature should be included as a key variable in modelling and risk assessment of coastal change on wave-dominated, sandy coastlines.

\section{Introduction}

Along low-lying, wave-dominated, sandy coastlines, a variety of physical processes affect shoreline change across a wide range of spatial and temporal scales. Despite their vulnerability to storms and sea-level rise - event-driven and chronic natural hazards - these environments tend to be intensively developed (Wong et al., 2014), motivating efforts to quantify present and historical rates of shoreline change and assess erosion risk, in the U.S. (Gornitz et al., 1994; Morton et al., 2004; Morton and Miller, 2005; Morton et al., 2005; Hapke et al., 2006; Hapke and Reid, 2007; Hapke et al., 2011; Fletcher et al., 2012; Hapke et al., 2013; Ruggiero et al., 2013; Gibbs and Richmond, 2015; Armstrong \& Lazarus, 2019) and internationally (e.g., Shaw et al.; 1998; Coelho et al., 2006; Nicholls and Vega-Leinert, 2008). Related to this empirical work are efforts to explain past and predict future trends in shoreline behavior with numerical models of coastal processes and environmental conditions (Ruggiero et al., 2010; Gutierrez et al., 2011; Yates and Cozannet, 2012; Hapke et al., 2013; Plant et al., 2016; Vitousek et al., 2017). However, modelled and observed shoreline changes on sandy coastlines still tend to show poor agreement over larger spatial $\left(>10^{1} \mathrm{~km}\right)$ and longer temporal (>10 $\left.{ }^{1} \mathrm{yr}\right)$ scales (e.g., Gutierrez et al., 2011; Yates and Cozannet, 2012; French et al., 2016). The number and variety of controls and processes that can affect sandy shoreline change, including sea-level rise (Leatherman et al., 2000; Plant et al., 2016; Moore et al., 2010; Murray and Moore, 2018; Moore et al., 2018; Ashton and Lorenzo-Trueba, 
2018); anthropogenic modifications (Johnson et al., 2015; Smith et al, 2015; Hapke et al., 2013; Armstrong \& Lazarus, 2019; Miselis and Lorenzo-Trueba, 2017; Rogers et al., 2015); geologic substrate (Valvo et al, 2006; Lazarus and Murray, 2011; Moore et al., 2010; Hauser et al., 2018; Cooper et al., 2018), nearshore bathymetry (Schupp et al., 2006; McNinch, 2004; Browder and McNinch 2006), and regional geography (Plant et al., 2016; Cooper et al., 2018); wave climate (Slott et al., 2010; Antolinez et al., 2018; Anderson et al., 2018); and sediment grain size (Komar 1998; Dean and Dalrymple, 2002), makes determining their relative contributions difficult, whether empirically or with numerical modelling. The influence of these factors changes with spatial scale (List et al., 2006; Lazarus et al., 2011) and at regional scales, a key but commonly overlooked driver of shoreline change is planform curvature.

Here, we examine a correlation between shoreline curvature and shoreline change along $\sim 1700 \mathrm{~km}$ of sandy reaches of the U.S. Atlantic and Gulf Coasts (Figure 1), over multiannual to centennial time scales. This analysis spans spatial and temporal scales an order of magnitude larger than those considered previously (Lazarus and Murray, 2007, 2011; Lazarus et al., 2011, 2012). Research into coastal vulnerability at large spatial scales has tended to focus on shoreline transgression due to sea-level rise (Gornitz et al., 1994; FitzGerald et al., 2008; Shaw et al., 1998; Hinkel and Klein, 2009; Gutierrez et al., 2011; Plant et al., 2016). While sea-level rise can drive long-term coastal erosion (Leatherman et al., 2000; Pilkey and Cooper 2004; Moore et al., 2010; Vitousek et al., 2017), so can interactions between incident offshore waves and subtle changes in shoreline planform curvature (Figure 2a), by setting up gradients in net alongshore sediment transport that generate spatial patterns of shoreline erosion and accretion (Dean and Yoo, 1992; Cowell et al., 1995; Valvo et al., 2006; Lazarus and Murray, 2007, 2011; Lazarus et al., 2011). (In this context, "offshore waves" refers to waves seaward of the inner continental shelf edge.) 
At any point along the shoreline planform, the magnitude of alongshore sediment flux can be related to significant wave height and relative angle between the incident offshore wave crest and the shoreline orientation (Falques, 2003; Ashton and Murray, 2006a). This wave-driven alongshore sediment flux is maximized for relative angles of $\sim 45^{\circ}$. When prevailing waves approach from "low angles" (relative angles less than the flux-maximizing angle), gradients in alongshore transport tend to diverge at convex-seaward (promontory) segments of the shoreline, causing erosion, and converge at concave-seaward (embayed) segments, causing accretion (Ashton et al., 2001; Falques, 2003; Ashton and Murray, 2006a; Arriga et al., 2017). Conversely, under a "high angle" wave climate, these gradients in net sediment transport are reversed, such that large-scale coastline curvature tends to increase over time and emergent planform features develop (Ashton et al. 2001; Falques, 2003; Ashton and Murray, 2006a, 2006b; Murray and Ashton, 2013; Idier et al., 2017; van den Berg et al., 2012). In most locations, on some days the offshore waves approach from high angles relative to the local shoreline orientation, and on some days they approach from low angles. Whether a coastline experiences net roughening or net smoothing depends on the wave climate; when there is a greater influence on alongshore transport from low angle offshore waves, a net smoothing results, and vice versa. (This distinction in terms of offshore waves applies in the limits of large alongshore length scales, relative to the cross-shore extent of the shoreface. On alongshore scales smaller than a few kilometers, for open ocean coasts, interactions between wave transformation and the curvature of seabed contours (Falques and Calvete 2005; Falques et al 2011) increase the proportion of high-angle offshore wave influence needed to cause coastline roughening.) Transport gradients tend to be larger (altering the coastline shape more rapidly) where shoreline curvature is high, but even subtle variations in curvature (involving a small range of shoreline angles) can drive shoreline change (Valvo et al., 2006; Lazarus and Murray, 2007). 
Where shoreline planform curvature is low, long-term coastline evolution can be described with a diffusion equation, such that positive diffusivity corresponds to coastline smoothing and negative diffusivity corresponds to coastline roughening (Ashton and Murray, 2006a,b; Falques 2003; Ashton and Murray 2003; Ashton et al 2003). Given that extensive reaches of the U.S. Atlantic and Gulf Coasts feature low curvatures with local wave climates tending to be low-angle dominated (e.g. Ashton and Murray, 2006b; Johnson et al., 2015), a diffusive, smoothing signal should be apparent over large spatial and long time scales across a broad span of locations. In numerical modeling experiments, even where regional high-angle wave climates (relative to the regional coastline trend) have shaped large-scale, emergent coastline features, such as cuspate capes or free spits, wave-shadowing effects and local shoreline reorientation result in diffusive prevailing conditions everywhere but near the cape tip or spit terminus (Ashton and Murray, 2006a, 2006b; Ashton et al., 2016). Thus, model results and observations (or hindcasts) of local wave climates lead us to expect a coastline-smoothing signal, i.e. positive diffusivity, in almost all locations (Ashton and Murray, 2006b). On the other hand, how much the diffusive, low-angle waves dominate local wave climates varies from region to region (e.g Johnson et al., 2015), leading to the prediction that coastline diffusion should be more dominant in some regions than others.

Because diffusion of large-scale coastal features theoretically occurs more slowly than for small-scale ones (the characteristic timescale for coastline change, $T$, scales with the square of the alongshore length scale, $L ; T \propto L^{2}$ ), to detect the influence of larger-scale (> $\mathrm{km}$ ) coastline curvature should require longer-term $\left(>10^{1} \mathrm{yr}\right)$ shoreline comparisons.

Theoretical and numerical-model-based predictions for how shoreline change should be related to coastline curvature have not often been directly tested against observations. We build on work by Lazarus and Murray (2007) that identified a negative correlation between 
shoreline curvature and shoreline change (i.e., where planform curvature was offshore convex, defined as positive, shoreline change was landward, defined as negative; Figure $2 b$ ) along $\sim 100 \mathrm{~km}$ of the Northern Outer Banks of North Carolina (USA). The correlation was

statistically significant at $10^{2}-10^{3} \mathrm{~m}$ spatial scales and multi-annual time scales (Figure S1). Here, we identify a predominant smoothing signal (a negative correlation between shoreline curvature and shoreline change) on the wave-dominated, sandy shorelines of the U.S.

Atlantic and Gulf Coasts over decadal to centennial time scales and multi-km spatial scales.

\section{Methods}

We analyzed shoreline curvature and change for coastal barriers along the U.S. Atlantic and Gulf Coasts, spanning a total of $\sim 1700 \mathrm{~km}$.

\subsection{Shoreline curvature}

To calculate shoreline curvature, we downloaded shorelines from the Geophysical Data System (GEODAS) Coastline Extractor v 1.1.3

(https://www.ngdc.noaa.gov/mgg/geodas/geodas.html). Shorelines in the Coastline Extractor come from the Global Self-consistent, Hierarchical, High-resolution Geography (GSHHG) database (Wessel and Smith, 1996) and are based on the World Vector Shoreline Data. After importing the shorelines from the Coastline Extractor into ArcGIS, we divided them into sections defined by morphologic (e.g., inlets) and anthropogenic (e.g. groynes) boundaries.

In ArcGIS, we set points at $1 \mathrm{~m}$ increments along each shoreline segment and created a reference line by linking the segment endpoints. We moved the reference line 2000-3000 m offshore so that the entirety of the shoreline was on the landward side of the reference line, which serves as an arbitrary datum for defining cross-shore positions. We assume the overall 
curvature of each segment is low, so that the distance along the reference line $(x)$ and the distance from the reference line $(y)$ correspond to $(x, y)$ coordinates for each point on the shoreline.

To isolate signatures of alongshore sediment flux related to coastline curvature, we removed $0.5 \mathrm{~km}$ from both ends of each shoreline section to reduce potential effects of inlets, which can cause convex bulges in the shoreline affected local changes in tidal deltas (Davis and Fitzgerald, 2004). However, where a jetty is present at the end of a shoreline section, we did not remove that terminal $0.5 \mathrm{~km}$, because the shoreline curvature (concave-seaward, negative curvature) and shoreline change (accretion; positive change) updrift of the jetty is a result of gradients in alongshore transport. Groynes result in the creation of locally concave and accreting shorelines updrift, similar to a jetty, but wave shadowing downdrift results in locally concave and eroding shorelines. Rather than distinguish between these two effects, we treat a groyne as an inlet and remove $0.5 \mathrm{~km}$ from both sides in our analysis.

We then filtered the $(x, y)$ shoreline sections with a running average weighted by a Gaussian distribution with a length scale of $\frac{L}{4}$ (where $L=1,3$, and $5 \mathrm{~km}$, respectively), to remove small-scale (high frequency) variations and reveal the large-scale curvature of the shoreline (Lazarus and Murray, 2007):

$$
f(x)=\frac{1}{\frac{L}{4} \sqrt{2 \pi}} e^{-\frac{1}{2}\left(\frac{x-\mu}{\frac{L}{4}}\right)^{2}}
$$

Truncating the tails of the Gaussian yields a total sum of the weights that is slightly less than $1(\sim 0.95)$. (The resulting shoreline positions could be multiplied by the inverse of this factor, to regain the full amplitude of the smoothed-shoreline undulations, although such a normalization would be canceled out in the correlation calculations, equation 2, and would 
thus not affect our results.) This truncation allowed us to retain more shoreline length for analysis, reducing the number of points needed to calculate a single value. This method differs slightly from that used in previous work (Lazarus and Murray, 2007), but results in filters of comparable size (Figure S2). Increasing the filter size reduces the number of data points obtainable from a given shoreline segment (because only points greater than half a smoothing window from the boundaries can be used); where a shoreline segment is not long enough to allow for smoothing at all three length scales $(1,3$, and $5 \mathrm{~km})$, we only examined the applicable scales. We calculated curvature as the second derivative of the smoothed shoreline, under the assumption that local shoreline orientations deviated little from the average orientation of the shoreline segment (Lazarus and Murray, 2007). (See Figure S3 for details of the analysis for an example shoreline segment.)

\subsection{Shoreline change}

We obtained shoreline change data separately, from the USGS National Assessment of Shoreline Change Project (Morton et al., 2004; Morton and Miller, 2005). Mean high water level was used to identify the shoreline. A "long-term" ( $\left.10^{2} \mathrm{yr}\right)$ rate of shoreline change for a given shoreline segment was obtained from a linear regression of shoreline change spanning the late-1800s, 1920s-1930s, 1970s, and 1998-2002. A "short-term" ( 10 $\left.{ }^{1} \mathrm{yr}\right)$ shoreline change rate was calculated using an end-point method, and shoreline data from the 1970s and 1998-2002. Positive values of shoreline change represent accretion; negative values represent erosion (Figure $2 b$ ). Where extensive reaches of a given shoreline segment did not have available shoreline-change data, we removed the segment from the analysis.

With the shoreline curvature and shoreline change data, we calculated a correlation coefficient (zero-lag) to determine the magnitude and sign of the relationship between curvature and shoreline change rate for each shoreline segment 


$$
\rho(A, B)=\frac{1}{N-1} \sum_{i=0}^{n}\left(\frac{A_{i}-\mu_{A}}{\sigma_{A}}\right)\left(\frac{B_{i}-\mu_{B}}{\sigma_{B}}\right)
$$

where $\mu_{A}$ and $\sigma_{A}$ are the mean and standard deviation of A (curvature), respectively, and $\mu_{B}$ and $\sigma_{B}$ are the mean and standard deviation of $\mathrm{B}$ (shoreline change rate). The absolute value of the correlation coefficients, which are nondimensional, is bounded by 0 (indicating no relationship between the two signals) and 1 (indicating that all of the variance in one signal is related to variance in the other signal). By our convention (Figure 2b), a negative correlation indicates shoreline smoothing, and a positive correlation indicates shoreline roughening.

We also identified shoreline segments that have experienced nourishment (Miller et al., 2004; Miller et al., 2005). We excluded nourished segments from our analysis of North Carolina and Florida but have included nourished segments from Texas and the Mid-Atlantic to demonstrate the effects of nourishment on this type of analysis. Nourished segments included in our calculations are identified in Table 1.

To provide context when analyzing the results of the correlation calculations for select regions (North Carolina, Texas, and Florida), we calculated an average effective diffusivity, representing the time-integrated effects of the high- and low-angle waves in the wave climate, following the methods of Ashton and Murray (2006b). Coastline diffusion can be expressed by:

$$
\frac{\partial y}{\partial t}=\frac{1}{D} \frac{\partial Q_{s}}{\partial \theta} \frac{\partial^{2} y}{\partial x^{2}}
$$

where $\partial y / \partial t$ is shoreline change rate, $\mathrm{D}$ is shoreface depth (the depth to which erosion or accretion are spread), and $\partial Q_{s} / \partial \theta$ is the rate of change of alongshore sediment flux as the relative angle between offshore wave crests and the local shoreline, $\theta$, varies - which is a 
function of relative angle and height of offshore waves. We can define coastline diffusivity $\mu$ as:

$$
\mu=\frac{1}{D} \frac{\partial Q_{S}}{\partial \theta}
$$

To represent the net diffusive (or antidiffusive) effects of a wave climate, we use an effective diffusivity (Ashton and Murray 2006b):

$$
\mu_{n e t}=\frac{\sum_{i=0}^{n} \mu_{i} \Delta t_{i}}{\sum_{i=0}^{n} \Delta t_{i}}
$$

where $\mu_{\text {net }}$ has dimensions of $\mathrm{m}^{2} / \mathrm{s}$. (Wave data are typically available as statistics such as significant wave height and wave direction averaged over a sampling period $\Delta \mathrm{t} ; \mu_{i}$ is calculated for each data point using Equation 4.) This effective diffusivity is 0 when the diffusive influence of all the low-angle waves in a wave climate equals the anti-diffusive influence of all the high-angle waves. Greater positive magnitudes of $\mu_{\text {net }}$ result from a greater dominance of low-angle waves, and or larger wave heights (holding the proportion of influences from low- and high-angle waves constant). Greater negative magnitudes of $\mu_{\text {net }}$ result from a greater dominance of high-angle waves, and or larger wave heights (holding the proportion of influences from low- and high-angle waves constant). In either case, positive or negative, the magnitude can in principle be large (e.g. > 1). The rate that subtle coastline undulations are smoothed out (or exaggerated) depends on the magnitude of $\mu_{n e t}$.

\subsection{Excluded reaches}

We excluded from this analysis much of the wave-dominated, sandy coastline of South Carolina and Georgia. This stretch of coast is characterized by a large tidal range, and frequent tidal inlets as well as estuaries; ocean-facing shoreline segments are therefore short, 
and the influence of tidal inlets is strong. We also excluded segments that are extensively stabilized and heavily developed in North Carolina and Florida.

\section{Results}

The full spatial extent of our analysis is shown in Figure 1 and data are reported in Table 1. Here, we examine subsets of those results in detail.

\subsection{North Carolina}

3.1.1 Comparison to previous work

Lazarus and Murray (2007) previously analyzed correlations between curvature and shoreline change along a section of the Northern Outer Banks of North Carolina from the Virginia state line to Oregon Inlet (NC P96 in this study). Because here we use a somewhat different method, we focused on the same section and re-analyzed the original data from that work (which extracted shoreline position from repeated lidar surveys) to make a direct quantitative comparison. Where Lazarus and Murray (2007) smoothed the calculated curvature and shoreline-change values, we smooth the shoreline itself. Comparing the results of smoothing the calculated curvature versus smoothing the shoreline, we found no difference in the final curvature values. Likewise, we found a negligible difference in the correlation coefficients for smoothing (Lazarus and Murray, 2007) or not smoothing (this study) the shoreline-change data.

The smoothing filters used in the respective analyses differ slightly (Figure S2). Our results thus differ in local detail, but not in overall trend. When we change the shape of our Gaussian so that it resembles the Hanning window used by Lazarus and Murray (2007), such that the 
sum of the weights is $\sim 99 \%$ and the lowest weight is $\sim 1 \%$ of the central value, the length scales of the respective filters differ by a factor of $\sim 1.5$ : data smoothed at a $1 \mathrm{~km}$ scale in our analysis is comparable to smoothing at a $\sim 1.5 \mathrm{~km}$ scale by the process in Lazarus and Murray (2007). We have to reduce our length scale $\left(\frac{L}{4}\right.$ in Equation 1$)$ by $\sim \frac{2}{3}$ to weight our Gaussian in a way that is comparable to their Hanning window.

Our method reproduced the same relationships demonstrated by Lazarus and Murray (2007; Figure S2), with values within a factor of 2 of those they reported (Table S1). The correlation between shoreline curvature and shoreline change is strongest at longer (decadal) time scales, and it depends on length scale in a way that varies with time scale (Figure S2).

\subsubsection{New analysis}

We analyzed $\sim 265 \mathrm{~km}$ of sandy barrier island shoreline along North Carolina's coast - more than twice the reach covered previously (Lazarus and Murray, 2007, 2011; Lazarus et al., 2011, 2012). Individual islands range in length from 2.7 to $121.44 \mathrm{~km}$. We removed several nourished shoreline segments from the analysis (NC 77, 79, 82, 86, 93, 94, 95; Table 1) and a few of the shoreline reaches $(\mathrm{NC} 84,85,91)$ are too short to be analyzed at all three length scales.

For context, we calculated a representative effective diffusivity of $0.992 \mathrm{~m}^{2} / \mathrm{s}$ for North Carolina (see Table S2 for details on shoreline sections and wave data used). Thus, we would expect correlations between curvature and shoreline change to be negative, corresponding to coastline smoothing. At the $1 \mathrm{~km}$ smoothing scale, almost all (85\%) of the shoreline has a significant correlation (using a 95\% confidence interval criterion) between shoreline curvature and short-term shoreline change (Table; Figure 3). This percentage decreases to $\sim 16 \%$ at the $5 \mathrm{~km}$ scale. The percentage of the shoreline with a significant positive 
correlation, indicating roughening, decreases from nearly $70 \%$ at the $1 \mathrm{~km}$ scale to $\sim 5 \%$ at 5 $\mathrm{km}$. This indicates small-scale roughening and large-scale smoothing over decadal time scales. Approximately $50 \%$ of the shoreline has a significant, negative correlation between shoreline curvature and long-term shoreline change at all spatial scales considered, indicating long-term (century-scale) smoothing. Significant correlation coefficients range from -0.83 to 0.55 for short term shoreline change and -0.91 to 0.59 for long-term (Table 1$)$. Stronger magnitude correlations (both positive and negative) tend to occur at large spatial scales.

Some of the significant roughening signals can be explained by local factors. For example, Shackleford Banks (NC 87) has a significant, positive correlation at the 3 and $5 \mathrm{~km}$ scales for both short- and long-term shoreline change (Figure 3). This apparent roughening signal likely arises from wave shadowing effects leading to a local gradient in wave climate where the western end of the island is more strongly affected by waves from the east and northeast than the eastern end. The resulting gradient in net alongshore sediment transport causes shoreline erosion creating a concave shoreline. The association between concavity and erosion corresponds to a roughening signal in our analysis.

Another island with a roughening signal, Figure Eight Island (NC 80), is known to undergo nourishment (which we address in Section 4.3). However, because it is a private island, and its nourishment projects are funded privately, Figure Eight Island is not included in the database we used to eliminate nourished shorelines. Browns Island (NC 84), a third island where shoreline roughening is apparent, is occupied by Camp Lejeune, a U.S. military base, and shoreline stabilization data are not available. In addition, some of the short-term roughening signals may indicate that local wave climates were weighted toward high-anglewave influence over relatively short durations, possibly related to single storm events involving large waves approaching from high angles (Lazarus et al., 2012). Because coastline 
diffusion or anti-diffusion theoretically occurs more rapidly as the spatial scale is reduced, the fact that the short term positive correlations tend to occur at the smallest length scales is consistent with the theoretical framework-especially given that larger scale and longer term correlations strongly tend to be negative, consistent with the positive effective diffusivity representing relatively long-term forcing.

\subsection{Texas}

We analyzed $\sim 575 \mathrm{~km}$ of sandy, barrier island shoreline along the Gulf Coast of Texas. Individual islands ranged in length from 10.2 to $95.9 \mathrm{~km}$. The shoreline sections for TX 2 (South Padre Island), 11, 12 and 13 (Galveston Island) have experienced nourishment but were included in the analysis for the sake of discussion. For context, we calculated an average effective diffusivity of $1.089 \mathrm{~m}^{2} / \mathrm{s}$ for Texas (Table S2); we expect to find correlations indicating coastline smoothing for this region.

The percentage of shoreline with a significant correlation between curvature and short-term shoreline change increases from $15 \%$ to $90 \%$ with increasing spatial scale (Table 2). Significant correlations are almost entirely negative, indicating smoothing (Figure 4). This significant smoothing signal is also observed for long-term shoreline change, though for a smaller percentage of the shoreline (9-24\%). Correlation coefficients range from -0.75 to 0.06 for short term shoreline change, and from -0.63 to 0.1 for long-term shoreline change (see Table 1 for all data). The correlation coefficients increase in maximum magnitude and range as the spatial scale increases (Figure 4, Table 1). While smoothing occurs at all three spatial scales $(1,3$, and $5 \mathrm{~km})$, values are more negative and there are more significant values (i.e. the smoothing signal is stronger) at larger spatial scales.

While a few shorelines in Texas appear to have a roughening signal, the correlations in these cases are much smaller in magnitude than those of the smoothing signal and are often not 
significant (Figure 4; Table 1). In most cases, this signal can be explained by local history. For example, Texas 8 (Figure S3) has a positive correlation coefficient indicating roughening for the 3 and $5 \mathrm{~km}$ smoothing windows at both short- and long-time scales (this signal is significant only at the $5 \mathrm{~km}$, long-term scale; Figure 4). Historical satellite imagery (via Google Earth), reveals that an inlet was formerly present in this location which has now filled in. Since the inlet closed during the period covered by our shoreline change data, this roughening signal is likely the result of the shoreline becoming locally convex in shape, while accreting seaward, as waves swept the relict ebb tidal delta onshore. Texas 12 also exhibits a significant, positive (roughening) signal on 3 and $5 \mathrm{~km}$ scales for short-term shoreline change (Figure 4a). This is likely a result of the island's history of nourishment projects resulting in the creation of a shoreline convexities. The correlations for the other nourished shoreline sections in Texas are not significant, close to zero, and/or negative (Table $1)$.

3.3 Mid-Atlantic (New York to Virginia)

We analyzed $\sim 485 \mathrm{~km}$ of sandy, barrier island shoreline between Montauk Point, New York and Assateague Island, Virginia. Individual islands range in length from 9.26 to $79.86 \mathrm{~km}$. Virtually all the shorelines along the coast of New York and New Jersey have been nourished or have stabilization structures such as groynes or seawalls in place; thus, all shorelines were included in the analysis regardless of nourishment or stabilization.

Approximately $50 \%$ of the shoreline has a significant correlation between shoreline curvature and short-term shoreline change at all spatial scales considered (Table 2; Figure 5). The percentage of the shoreline with a significant positive correlation, indicating roughening, increases from $10 \%$ to $30 \%$ as spatial scale increases from 1 to $5 \mathrm{~km}$. For long-term shoreline change, the percentage of the shoreline with a significant correlation increases from $50 \%$ to 
$70 \%$ with increasing spatial scale. Approximately $50 \%$ of the shoreline has a significant positive correlation between curvature and long-term shoreline change, on all spatial scales. These mainly positive correlations reflect the long-term roughening signal of shoreline stabilization and nourishment on the heavily developed barriers of the mid-Atlantic (Hapke et al., 2013), which obscures the smoothing signal that would be expected. The relatively few smoothing signals occur predominately in the short-term analysis. Correlation coefficients in this region range from -0.42 to 0.73 for long-term change, and from -0.83 to 0.55 for shortterm change (Table 1).

One of the shoreline sections, NY 4 (Fire Island, Figure 5), displays a roughening signal on both short-term and long-term timescales despite not undergoing nourishment. This signal can be attributed to the presence of shoreface-attached sand ridges acting as an offshore sediment source (Safak et al., 2017; Section 4.3).

\subsection{Virginia}

The Virginia Barrier Islands are characterized by short, uninhabited islands with a strong tidal influence. Islands range in length from 3.09 to $15.69 \mathrm{~km}$. Tidal and inlet effects are at least as important as wave influence in determining island behavior in this region. Many of the shorelines are too short to evaluate at greater than the $1 \mathrm{~km}$ length scale, and others (e.g. Wallops Island, a NASA flight facility) do not have historic shoreline change data available. In addition, the timescales of analysis in this project do not match the timescales of shoreline change in this region. While our shoreline change data is on decadal or centurial time scales, the tidal-inlet dynamics cause the Virginia Barrier Islands to rotate and shift on shorter timescales, so that there is little overlap between the current position (and curvature) of the shoreline and the position (and curvature) of the shoreline at the start of the time spanned by the shoreline change data. For one example, Hog Island, shoreline change rates can be higher 
than $5 \mathrm{~m} / \mathrm{yr}$, rotating the island by accreting on the northern end of the island and eroding on the southern (Hayden et al., 1991) and resulting in changes in shoreline location of hundreds of meters over the timescales of our analysis.

As a result of the mismatch between shoreline change rates and the duration over which shoreline change is calculated in this study, no clear trend can be found, and most coefficients are on the extreme ends of the range of correlations, signifying a strong smoothing or roughening signal (see Table 1 for data). Many of the islands are short enough that few points remained for analysis, allowing outliers to have a strong influence on the overall trend. Few correlations are significant, and the mismatch in timescales means it is unlikely the trends have any physical meaning, especially on timescales as long as 100 years. While positive correlations could represent curvature-related roughening resulting from locally anti-diffusive wave climates, the mismatch between the time scales of our analysis and those of the shoreline changes in this region preclude meaningful interpretation. Although we did not perform our analysis for the short, tidally-influenced barrier islands of South Carolina and Georgia, we would expect similar results for those shorelines.

\subsection{Florida}

Though characterized by long sandy barriers like the coasts of North Carolina and Texas, the Florida coast is also heavily developed and therefore subject to large and frequent nourishment projects. Due to the extent of nourishment, we analyzed only a portion of the Florida coast: $\sim 280 \mathrm{~km}$ of sandy barrier-island shoreline along the eastern coast of Florida. This included eight shorelines, ranging from 16.41 to $60.72 \mathrm{~km}$ in length. For context, we calculated a representative effective diffusivity of $2.575 \mathrm{~m}^{2} / \mathrm{s}$ for Florida (Table S2), corresponding to the prediction of strong smoothing signals (negative correlations between curvature and shoreline change). 
Between $47-73 \%$ of the shoreline considered had a significant correlation between curvature and short-term shoreline change, for which smoothing signals dominate on larger spatial scales and roughening over smaller (Table 2; Figure 6). Less of the overall shoreline has a significant correlation when examining long-term shoreline change, but the correlation is more likely to be negative, reflecting a smoothing signal (Figure 6).

\section{Discussion}

\subsection{Variability in Wave Climate and Effective Diffusivity}

Correlations between curvature and shoreline change depend on local wave climates, which vary alongshore. Even though the regional wave climate affecting the Carolina coast is marginally anti-diffusive (i.e. a negative diffusivity, giving rise to the capes and cuspate coastline; Ashton and Murray, 2006a), numerical modeling indicates that wave-shadowing effects and coastline rotation combine to produce diffusive local wave climates (Ashton and Murray, 2006b), tending to keep shorelines smooth in the bays between the capes. Texas (and Florida) are simpler in this sense, with local wave climates that are approximately the same as the regional wave climates.

North Carolina and Texas have very similar local wave climates, as measured by the effective diffusivity for representative shoreline segments (Table S2). We might therefore expect the correlations between curvature and shoreline change (i.e the distribution of correlation coefficients) to be similar. However, even with the inclusion of nourished shorelines in Texas and not North Carolina, correlations are on average more negative for Texas than North Carolina (i.e. the distribution is shifted to the left; Figure 7). A larger percentage of the shoreline exhibits a smoothing signal in Texas (Table 2), and correlations tend to be stronger than North Carolina. When roughening signals are observed, they are less likely to be significant and tend to be smaller for Texas than North Carolina. 
What might explain this difference? In terms of theoretical frameworks and numerical model results, the likely answer involves wave-shadow effects, which play a key role in shaping the coastline of North Carolina but not Texas. The gradient in net alongshore sediment transport associated with a wave-shadow gradient tends to produce erosion, and therefore coastline concavity (as with Shackleford Banks, NC 87, in section 3.1.2). However, as the concave curvature increases in magnitude, the component of the alongshore-transport gradient related to coastline curvature increases. This component of the gradient in net transport tends to cause accretion. In modeling studies (and likely on natural coastlines), as the curvature increases, the tendency to accrete (driven by coastline curvature) eventually balances the tendency to erode (driven by a wave-shadow gradient). Although fluctuations in wave climate will cause the curvature to fluctuate (Ratliff \& Murray, 2014), the result is a background curvature in a quasi-steady state - such as the curvature observed in the cuspate bays between capes. (In the case of Shackleford Banks in NC, the curvature was presumably in quasi-steady state before Barden's Inlet opened up in 1933, disconnecting the cape from Cape Lookout from the Shackleford Banks shoreline. Because of the disconnection in the sediment transport pathway, which changed the boundary condition at the eastern end of the Shackleford shoreline, over the last several decades the curvature of the shoreline has been decreasing as the eastern end erodes.)

In the quasi-steady state, this background curvature theoretically does not contribute to any accretion, nor does it contribute to the correlation between curvature and shoreline change. Instead, shoreline change in this context should be correlated with deviations from the background curvature. Where the curvature is greater than the background, accretion should result, and where the curvature is smaller than the background value, erosion should result. If we were able to calculate the background curvature, which will vary with position within a cuspate bay, and subtract the background from the observed curvature, we would expect the 
correlations to be stronger - approximately as strong in North Carolina as those in Texas.

Calculation of background curvature is beyond the scope of this work but is a valuable topic for future examination. For the present, the stronger correlations on the Texas coast, despite a very similar effective diffusivity to that representing the Carolina coast, is consistent with the theoretical/modeling framework.

\subsection{Space and Time Scales of Relevance}

In a simple diffusional system, we would theoretically expect to be able to see relationships between shoreline curvature and shoreline change down to small $(\mathrm{km})$ spatial scales for short time scales. However, the longer the span of time considered, the more likely it is that smallscale relationships are obscured, as the memory of small-scale shoreline excursions in the initial coastline diffuse away and the long-term shoreline position becomes dominated by larger scale undulations. This is consistent with our results which involve relatively longtimescale shoreline change data; there are stronger correlations for the larger spatial scales (i.e. $5 \mathrm{~km})$ than the smaller ones $(1,3 \mathrm{~km})$ and this trend is more evident for the centurial timescales than the decadal ones (see Figure 7, Tables 1 and 2).

The time and space scales over which our analysis is meaningful vary with the wide variety of environmental conditions and morphological processes which can affect shoreline change. In some cases, signals that did not fit our expectations were related to events in the history of a given shoreline reach, such as the creation or filling-in of an inlet. In these cases, shorelinechange data with the same time scale but from a different time period would likely have resulted in a smoothing signal. In other cases, such as the Virginia Barrier Islands, the timescale of the shoreline-change data sets does not match the timescale for the reshaping of the shoreline. When the final shoreline shape differs so dramatically from the initial shape 
(and from the shape at intermediate times), the record of cumulative shoreline change does not bear a strong relationship to the curvature of the final shoreline.

If the fact that shoreline change operates on a shorter timescale than our decadal and centurial shoreline change timescales was the only obstacle, we could overcome it by using shorterterm (e.g. annual) shoreline change data. However, the strong tidal influence and rotational nature of the short Virginia Barrier Islands means that waves are not the only strong influence shaping these islands. While gradients in wave-driven alongshore transport are tending to smooth out some portions of the coastline, tidal-inlet processes are generating or exaggerating shoreline bulges in other portions. This combination of smoothing and roughening signals means we would not necessarily expect shoreline curvature to have a simple relationship with shoreline change rates. These examples lead to a broader consideration of processes that can create shoreline curvature, in opposition to the tendency for alongshore-transport gradients reduce curvature.

\subsection{Nourishment and Other Complicating Factors}

Along with tidal-inlet processes, other processes can introduce shoreline change signals that complicate or obscure the relationship between shoreline curvature and shoreline change. These processes range from shoreline bulges resulting from nourishment (Dean and Yoo, 1992; Browder and Dean, 2000; Dean 2002) to variations in underlying geology (Valvo et al., 2006).

In the case of nourishment, if shoreline change and curvature were analyzed during a period following the completion of a nourishment project and before any subsequent nourishments, the results would indicate smoothing, as the convex nourished beach erodes and surrounding convex shorelines accrete (e.g. Dean and Yoo, 1992; Browder and Dean, 2000; Dean 2002). However, if nourishment occurs during the period analyzed, the artificial widening of the 
shoreline and corresponding shoreline convexity in the in final shoreline shape looks like a roughening signal. On the timescales considered in our analysis, multiple nourishment episodes can obscure diffusional signals from waves. This result (Figure 5) resonates with the previous finding concerning the highly developed coasts of the mid-Atlantic: Shorelines which in historic times experienced shoreline erosion are now exhibiting net accretional shoreline change signals resulting from the cumulative impact of nourishment projects (Hapke et al., 2013; Armstrong \& Lazarus, 2019). Over long timescales the natural erosional signal appears completely obscured by human activity.

Heterogeneity in underlying geology or offshore bathymetry can also create signals of shoreline change. Offshore bathymetric features, such as shoreface-attached sand ridges, can influence both shoreline shape and shoreline change. Fire Island (NY 4), provides a clear example, displaying a roughening signal on scales greater than $1 \mathrm{~km}$ in our analysis (Figure 5, Table 1), likely caused by the presence of shoreface-connected sand ridges offshore (Safak et al., 2017). These features apparently act as a cross-shore source of sediment, resulting in accretion and subtle convex bumps along the shoreline. In a low-angle wave climate such as is found here, we would expect gradients in alongshore sediment transport associated with the convex curvature to result in erosion. However, in this case it appears that the rate of crossshore sediment flux building the undulations is greater than the rate sediment is being removed by alongshore transport gradients related to shoreline curvature.

Alongshore variations in the composition of underlying geology can also create persistent perturbations to shoreline curvature (Lazarus and Murray, 2011; Valvo et al., 2006). As an eroding coastline encroaches on alongshore heterogeneities in the material that the shoreface is eroding into, portions of the coastline that are producing less material that is coarse enough to stay in the nearshore system will begin to erode more rapidly, producing concave 
curvature. Conversely, portions of the coastline where the shoreface is eroding into coarser material will tend to produce subtle convex bumps in the coastline (Lazarus and Murray, 2011; Valvo et al., 2006). This curvature tends to be diffused away by the smoothing action of waves, but new shoreline curvature signals are introduced as the shoreline transgresses through alongshore-variable substrate (Lazarus and Murray, 2011). The reintroduction of these signals could explain why shorelines on even wave-dominated, pristine coastlines that are being diffused still retain curvature after millennia of smoothing (Lazarus and Murray, 2011).

\subsection{Implications}

Our results demonstrate that shoreline curvature can correlate significantly with shoreline change rates over several kilometer and decade to century space and time scales. The presence of a significant correlation between shoreline change and shoreline curvature on many coastlines, however small the correlation coefficient may be, demonstrates the importance of this relationship in understanding shoreline dynamics. This relationship is strongest on wave-dominated coasts with long, sandy barriers and relatively slow rates of shoreline change, but can help explain shoreline behavior even on shorter islands with competing influences (e.g. tides) over relatively short timescales.

The demonstrated role of shoreline curvature in determining shoreline change rates has implications for managing as well as for understanding sandy coasts. Large magnitude, significant correlations between shoreline curvature and shoreline change in some locations (e.g. Texas, North Carolina) suggest that considering shoreline curvature in analyses of historical and predicted shoreline change could help improve agreement between models and data on low-lying, sandy coastlines where models have historically underperformed (e.g.

Gutierrez et al., 2011; Yates and Cozannet, 2012). Although practical application is limited to 
wave-dominated coastlines, this analysis is broadly applicable to many types of shoreline and shoreline-change data, across a range of time and space scales. Calculating shoreline curvature is relatively straightforward, and we show that the results of correlation analyses exhibit low sensitivity to variations in methodology (see Section 3.2.2). Thus, the results presented here suggest that correlations between curvature and shoreline change should be included in risk assessment and modelling efforts pertaining to sandy shorelines.

\section{Acknowledgements}

A grant from the National Science Foundation, Dynamics of Coupled Natural-Human Systems Program (ICER-1715638) supported this work. We also thank Evan Goldstein and Andrew Ashton for insightful conversations. The shorelines used in this study can be downloaded from the Coastline Extractor at https://www.ngdc.noaa.gov/mgg/shorelines/, and the shoreline change data from https://pubs.usgs.gov/of/2004/1089/gis-data.html for Texas, https://pubs.usgs.gov/of/2010/1119/ for the mid-Atlantic, and https://pubs.usgs.gov/of/2005/1326/ for the southeast. The correlation coefficients presented in this study can be found in Table 1 . The code used to calculate effective diffusivity can be found here: https://github.com/kennethells/wispy.git. 


\section{References}

Anderson, D., P. Ruggiero, J. A. A. Antolínez, F. J. Méndez, and J. Allan (2018), A Climate Index Optimized for Longshore Sediment Transport Reveals Interannual and Multidecadal Littoral Cell Rotations, Journal of Geophysical Research: Earth Surface, doi:10.1029/2018jf004689.

Antolinez, J. A. A., Murray, A. B., Mendez, F. J., Moore, L. J., Farley, G., and J. Wood (2018), Downscaling Changing Coastlines in a Changing Climate, the Hybrid Approach, Journal of Geophysical Research: Earth Surface, 123.

https://doi.org/10.1002/2017JF004367.

Armstrong, S. B., \& Lazarus, E. D. (2019). Masked shoreline erosion at large spatial scales as a collective effect of beach nourishment. Earth's Future, 7.

https://doi.org/10.1029/2018EF001070

J. Arriaga a, J. Rutten, F. Ribas, A. Falques, G. Ruessink (2017). Modeling the long-term diffusion and feeding capability of a mega-nourishment. Coastal Engineering, 121, 1-

13. https://doi.org/10.1016/i.coastaleng.2016.11.011Ashton A, Lorenzo-Trueba J. 2018.

Morphodynamics of barrier response to sea-level rise. In Barrier Dynamics and Response to

Changing Climate (eds L. J. Moore and A. B. Murray). New York, Springer.

Ashton A, Murray, A. B., and O. Arnoult (2001), Formation of coastline features by largescale instabilities induced by high-angle waves. Nature 414: 296-300. DOI:

http://dx.doi.org/10.1038/35104541

Ashton, A., List, J.H., Murray, A.B., and A. S. Farris (2003), Investigating links between hotspots and alongshore sediment transport using field measurements and simulations, Coastal Sediments '03. 
Ashton, A. D., and A. B. Murray (2006a), High-angle wave instability and emergent shoreline shapes: 1. Modeling of sand waves, flying spits, and capes. Journal of Geophysical Research 111. DOI: 10.1029/2005jf000422

Ashton, A. D., and A. B. Murray (2006b), High-angle wave instability and emergent shoreline shapes: 2. Wave climate analysis and comparisons to nature. Journal of Geophysical Research 111. DOI: 10.1029/2005jf000423

Ashton, A.D., Nienhuis, J., and K. Ells (2016), On a neck, on a spit: controls on the shape of free spits. Earth Surf. Dyn. 4.

Browder AE, and R. Dean (2000), Monitoring and comparison to predictive models of the Perdido Key beach nourishment project, Florida, USA. Coastal Engineering 39: 173-191. DOI: https://doi.org/10.1016/S0378-3839(99)00057-5

Browder, A. G., and J. E. McNinch (2006), Linking framework geology and nearshore morphology: Correlation of paleo-channels with shore-oblique sandbars and gravel outcrops, Marine Geology, 231(1-4), 141-162, doi:10.1016/j.margeo.2006.06.006.

Coelho C, Silva R, Veloso-Gomes F, and F. Taveira Pinto (2006), A vulnerability analysis approach for the Portuguese West Coast. In Risk Analysis V: Simulation and Hazard Mitigation; 251-262.

Cooper, J. A. G., Green A. N., and C. Loureiro (2018), Geological constraints on mesoscale coastal barrier behaviour, Global and Planetary Change, 168, 15-34, doi:10.1016/j.gloplacha.2018.06.006.

Cowell P. J., Roy P. S., and R. Jones (1995), Simulation of large-scale coastal change using a morphological behavior model. Marine Geology 126: 45-61

Davis R., and Fitzgerald D. 2003. Beaches and Coasts. Wiley 
Dean R. 2002. Beach Nourishment: Theory and Practice. World Scientific: Hackensack, N.J.

Dean, R. G. and R. A. Dalrymple (2002), Coastal Processes with Engineering

Applications. Cambridge, UK: Cambridge University Press.

Dean R., and C. H. Yoo (1992), Beach-nourishment performance predictions. Journal of Waterway, Port, Coastal, and Ocean Engineering 118:

Falqués A. (2003) On the diffusivity in coastline dynamics. Geophysical Research Letters 30. DOI: $10.1029 / 2003 \mathrm{~g} 1017760$

Falqués, A., and D. Calvete (2005), Large-scale dynamics of sandy coastlines: Diffusivity and instability, Journal of Geophysical Research: Oceans, 110(C3), doi:10.1029/2004jc002587.

FitzGerald DM, Fenster MS, Argow BA, and I. V. Buynevich (2008), Coastal Impacts Due to Sea-Level Rise. Annual Review of Earth and Planetary Sciences 36: 601-647. DOI: 10.1146/annurev.earth.35.031306.140139

Fletcher CH, Romine BM, Genz AS, Barbee MM, Dyer M, Anderson TR, Lim SC, Vitousek S, Bochicchio C, Richmond BM. (2012), National Assessment of Shoreline Change: Historical Shoreline Change in the Hawaiian Islands. U.S. Geological Survey Open-file Report 2011-1051:

French, J., Payo, A., Murray, A. B., Orford, J., Eliot, M., and P. Cowell (2016), Appropriate complexity for the prediction of coastal and estuarine geomorphic behavior at decadal to centennial scales, Geomorphology, 256, 3 - 16, http://dx.doi.org/10.1016/j.geomorph.2015.10.005 
Gibbs A. E., and B. M. Richmond (2015), National Assessment of Shoreline Change:

Historical Shoreline Change along the North Coast of Alaska, U.S.-Canadian Border to Icy

Cape. U.S. Geological Survey Open-file Report 2015-1048:

Gornitz V. M., Daniels R. C., White T. W., and K. R. Birdwell (1994), The development of a coastal risk assessment database: Vulnerability to sea-level rise in the U.S. southeast. Journal of Coastal Research 12: 327-338

Gutierrez B. T., Plant N. G., and E. R. Thieler (2011), A Bayesian network to predict coastal vulnerability to sea level rise. Journal of Geophysical Research 116. DOI:

10.1029/2010jf001891

Hapke C. J., Himmelstoss E. A., Kratzmann M. G., List J. H., and E. R. Thieler (2011).

National assessment of shoreline change. Historical shoreline change along the New England and Mid-Atlantic Coasts. U.S. Geological Survey Open-file Report 2010-1118:

Hapke C. J., Kratzmann M. G., and E. A. Himmelstoss (2013), Geomorphic and human influence on large-scale coastal change. Geomorphology 199: 160-170. DOI:

10.1016/j.geomorph.2012.11.025

Hapke C. J., and D. Reid (2007) National Assessment of Shoreline Change Part 4: Historical Coastal Cliff Retreat along the California Coast. U.S. Geological Survey Open-file Report 2007-1133:

Hapke C. J., Reid D., Richmond B. M., Ruggiero P., and J. H. List (2006), National Assessment of Shoreline Change Part 3: Historical Shoreline Change and Associated Coastal Land Loss Along Sandy Shorelines of the California Coast. U.S. Geological Survey Openfile Report 2006-1219: 
Hauser C., Barrineau P., Hammond B., Saari B., Rentschler E., Trimble S., Wernette P., Weymer B., and S. Young (2018), Role of the foredune in controlling barrier island response to sea level rise. In Barrier Dynamics and Response to Changing Climate (eds L. J. Moore and A. B. Murray). New York, Springer.

Hayden BP, Dueser RD, Callahan JT, Shugart HH. 1991. Long-Term Research at the Virginia Coast Reserve. BioScience 41: 310-318. DOI: 10.2307/1211584

Hinkel J, Klein RJT. 2009. Integrating knowledge to assess coastal vulnerability to sea-level rise: The development of the DIVA tool. Global Environmental Change 19: 384-395. DOI: 10.1016/j.gloenvcha.2009.03.002

Idier, D., A. Falques, J. Rohmer, and J. Arriaga, 2017, Self-organized kilometer-scale shoreline sand wave generation: Sensitivity to model and physical parameters, J. Geophys. Res. Earth Surf. 122, 1678-1697. doi:10.1002/2017JF004197.

Johnson, J.M, L.J. Moore, K. Ells, A.B. Murray, P.N. Adams, R.A. MacKenzie III, and J.M. Jaeger, 2015, Recent Shifts in Coastline Change and Shoreline Stabilization Linked to Storm Climate Change, Earth Surface Processes and Landforms. DOI: 10.1002/esp.3650

Komar, P. D. (1998), Beach Processes and Sedimentation. Englewood Cliffs, New Jersey: Prentice Hall.

Lazarus E, Ashton A, Murray AB, Tebbens S, Burroughs S. 2011. Cumulative versus transient shoreline change: Dependencies on temporal and spatial scale. Journal of Geophysical Research 116. DOI: 10.1029/2010jf001835

Lazarus ED, Murray AB. 2007. Process signatures in regional patterns of shoreline change on annual to decadal time scales. Geophysical Research Letters 34. DOI: 10.1029/2007g1031047 
Lazarus ED, Murray AB. 2011. An integrated hypothesis for regional patterns of shoreline change along the Northern North Carolina Outer Banks, USA. Marine Geology 281: 85-90. DOI: $10.1016 /$ j.margeo.2011.02.002

Lazarus, E. D., Ashton, A. D. and Murray, A. B. (2012). Large-scale patterns in hurricanedriven shoreline change. In Extreme Events and Natural Hazards: The Complexity

Perspective (eds A. S. Sharma, A. Bunde, V. P. Dimri and D. N. Baker), 139-152 doi:10.1029/2011GM001074

Leatherman SP, Zhang K, Douglass BC. 2000. Sea level rise shown to drive coastal erosion. EOS 81: $55-57$

List JH, Farris AS, Sullivan C. 2006. Reversing storm hotspots on sandy beaches: Spatial and temporal characteristics. Marine Geology 226: 261-279. DOI: 10.1016/j.margeo.2005.10.003

McNinch, J. E. (2004), Geologic control in the nearshore: shore-oblique sandbars and shoreline erosional hotspots, Mid-Atlantic Bight, USA, Marine Geology, 211(1-2), 121-141, doi:10.1016/j.margeo.2004.07.006.

Miller TL, Morton RA, Sallenger AH, and Moore LJ. 2004. The National Assessment of Shoreline Change: A GIS Compilation of Vector Shorelines and Associated Shoreline Change data for the U.S. Gulf of Mexico. U.S. Geological Survey Open-file Report 20041089

Miller TL, Morton RA, and Sallenger AH. 2005. The National Assessment of Shoreline Change: A GIS Compilation of Vector Shorelines and Associated Shoreline Change Data for the U.S. Southeast Atlantic Coast. U.S. Geological Survey Open-file Report 2005-1326. 
Miselis, J. L., and J. Lorenzo-Trueba (2017), Natural and Human-Induced Variability in Barrier-Island Response to Sea Level Rise, Geophysical Research Letters, 44(23), 11,922911,931, doi:10.1002/2017g1074811.

Moore, L. J., List JH, Williams SJ, and D. Stolper (2010), Complexities in barrier island response to sea level rise: Insights from numerical model experiments, North Carolina Outer Banks. Journal of Geophysical Research 115. DOI: 10.1029/2009jf001299

Moore, L. J., Goldstein EB, Duran Vinent O, Walters D, Kirwan M, Lauzon R, Murray, A. B.,, Ruggiero R. 2018. The role of ecomorphodynamic feedbacks and landscape couplings in influencing the response of barriers to changing climate. In Barrier Dynamics and Response to Changing Climate (eds L. J. Moore and A. B. Murray). New York, Springer.

Morton R. A., and T. L. Miller (2005), National Assessment of Shoreline Change: Part 2. Historical Shoreline Changes And Associated Coastal Land Loss Along The U.S. Southeast Atlantic Coast. U.S. Geological Survey Open-file Report 2005-1401:

Morton R. A., Miller T. L., and L. J. Moore (2004), National Assessment of Shoreline Change: Part 1, Historical Shoreline Change and Associated Coastal Land Loss along the U.S. Gulf of Mexico. U.S. Geological Survey Open-file Report 2004-1043:

Morton R. A., Miller T. L., and L. J. Moore (2005), Historical shoreline changes along the US Gulf of Mexico: A summary of recent shoreline comparisons and analyses. Journal of Coastal Research 21: 704-709

Morton R. A., Paine J. G., and J. C. Gibeaut (1994), Stages and durations of post-storm beach recovery, southeastern Texas coast, U.S.A. Journal of Coastal Research 10: 884-908 Murray, A.B., and Ashton, A., 2003, Sandy-coastline evolution as an example of pattern formation involving emergent structures and interactions, Coastal Sediments '03 
Murray, A. B., and A. D. Ashton (2013), Instability and finite-amplitude self-organization of large-scale coastline shapes, Philos Trans A Math Phys Eng Sci, 371(2004), 20120363, doi:10.1098/rsta.2012.0363.

Murray, A. B. and L. J. Moore (2018). Geometric constraints on long-term barrier migration: From simple to surprising. In Barrier Dynamics and Response to Changing Climate (eds L. J. Moore and A. B. Murray). New York, Springer.

Nicholls R. J., and A. C. Vega-Leinert (2008), Implications of sea-level rise for Europe's coasts: An introduction. Journal of Coastal Research 24: 285-287

Pilkey O.H., and J. A. G. Cooper (2004), Society and Sea Level Rise. Science 303: 17811782

Plant N. G., R. E. Thieler, and D.L. Passeri (2016), Coupling centennial-scale shoreline change to sea-level rise and coastal morphology in the Gulf of Mexico using a Bayesian network. Earth's Future 4: 143-158. DOI: 10.1002/2015ef000331

Ratliff, K. M., and A. B. Murray (2014), Modes and emergent time scales of embayed beach dynamics, Geophysical Research Letters, 41(20), 7270-7275, doi:10.1002/2014g1061680. Rogers, L. J., L. J. Moore, E. B. Goldstein, C. J. Hein, J. Lorenzo-Trueba, and A. D. Ashton (2015), Anthropogenic controls on overwash deposition: Evidence and consequences, Journal of Geophysical Research: Earth Surface, 120(12), 2609-2624, doi:10.1002/2015jf003634.

Ruggiero P, Buijsman M, Kaminsky GM, Gelfenbaum G. 2010. Modeling the effects of wave climate and sediment supply variability on large-scale shoreline change. Marine Geology 273: 127-140. DOI: 10.1016/j.margeo.2010.02.008 
Ruggiero P., Kratzmann M. G., Himmelstoss E. A., Reid D., Allan J., G. M. Kaminsky (2013), National Assessment of Shoreline Change: Historical Shoreline Change Along the Pacific Northwest Coast. U.S. Geological Survey Open-file Report 2012-1007:

Safak I., List J. H., Warner J. C., and W. C. Schwab (2017), Persistent Shoreline Shape Induced From Offshore Geologic Framework: Effects of Shoreface Connected Ridges. Journal of Geophysical Research: Oceans 122: 8721-8738. DOI: 10.1002/2017jc012808

Schupp, C. A., J. E. McNinch, and J. H. List (2006), Nearshore shore-oblique bars, gravel outcrops, and their correlation to shoreline change, Marine Geology, 233(1-4), 63-79, doi:10.1016/j.margeo.2006.08.007.

Shaw 0. J., Taylor R. B., Solomon S., Christian H. A., and D. L. Forbes (1998) Potential impacts of global sea-level rise on Canadian coasts. Canadian Geographer 42: 365-379

Slott, J. M., Murray, A. B., and A. D. Ashton (2010), Large-scale responses of complexshaped coastlines to local shoreline stabilization and climate change, Journal of Geophysical Research-Earth Surface, 115, F03033, doi:10.1029/2009JF001486.

Smith, M. D., Murray, A. B., Gopalakrishnan, S., Keeler, A. G., Landry, C. E., McNamara, D., and L. J. Moore (2015), Chapter 7 - Geoengineering Coastlines? From Accidental to Intentional, in Coastal Zones, Solutions for the $21^{\text {st }}$ Century, Elsevier, doi: 10.1016/B978-0$\underline{12-802748-6.00007-3}$

Valvo L. M., Murray, A. B., and A. Ashton (2006), How does underlying geology affect coastline change? An initial modeling investigation. Journal of Geophysical Research 111. DOI: $10.1029 / 2005 j f 000340$ 
van den Berg, N., A. Falques, F. Ribas (2012). Modeling large scale shoreline sand waves under oblique wave incidence. Journal of Geophys. Res, 117, F03019, doi:10.1029/2011JF002177.

Vitousek S., Barnard P. L., Limber P., Erikson L., B. Cole (2017), A model integrating longshore and cross-shore processes for predicting long-term shoreline response to climate change. Journal of Geophysical Research: Earth Surface 122: 782-806. DOI:

10.1002/2016jf004065

Wessel P., and W. H. F. Smith (1996), A global, self-consistent, hierarchical, high-resolution shoreline database. Journal of Geophysical Research: Solid Earth 101: 8741-8743. DOI:

10.1029/96jb00104

Wong, P.P., I. J. Losada, J.-P. Gattuso, J. Hinkel, A. Khattabi, K. L. McInnes, Y. Saito, and A. Sallenger (2014), Coastal systems and low-lying areas, in Climate Change 2014: Impacts, Adaptation, and Vulnerability. Part A: Global and Sectoral Aspects. Contribution of Working Group II to the Fifth Assessment Report of the Intergovernmental Panel on Climate Change, edited by C. B. Field et al. , pp. 361-409, Cambridge Univ. Press, Cambridge, U. K.

Yates M. L., and G. Le Cozannet (2012), Brief communication "Evaluating European Coastal Evolution using Bayesian Networks". Natural Hazards and Earth System Science 12: 11731177. DOI: $10.5194 /$ nhess-12-1173-2012 
Table 1. Correlation coefficient data for all space and time scales for all shoreline sections. Shoreline sections are numbered moving from south to north (e.g. New York 1 is the southernmost section of New York's shoreline). Bold shoreline section names have not experienced nourishment, unbolded section names have experienced nourishment. Bold values are significant at a 95\% confidence interval.

\begin{tabular}{|c|c|c|c|c|c|c|}
\hline \multirow{3}{*}{$\begin{array}{l}\text { Shoreline } \\
\text { section }\end{array}$} & \multicolumn{6}{|c|}{ Correlation Coefficient } \\
\hline & \multicolumn{3}{|c|}{ Short term shoreline change } & \multicolumn{3}{|c|}{ Long term shoreline change } \\
\hline & $1 \mathrm{~km}$ & $3 \mathbf{k m}$ & $5 \mathrm{~km}$ & $1 \mathrm{~km}$ & $3 \mathrm{~km}$ & $5 \mathrm{~km}$ \\
\hline New York8 & 0.070324 & -0.12827 & -0.1582 & -0.03502 & -0.20957 & -0.36577 \\
\hline New York7 & 0.111674 & 0.372689 & 0.129199 & -0.01643 & -0.26676 & -0.18264 \\
\hline New York6 & -0.16447 & -0.2139 & 0.094883 & 0.072898 & -0.35544 & -0.41847 \\
\hline New York5 & -0.04217 & -0.01076 & 0.02657 & -0.01125 & -0.02875 & -0.08844 \\
\hline New York4 & -0.00042 & 0.026879 & 0.164316 & -0.07888 & 0.202794 & 0.11143 \\
\hline New York3 & 0.019078 & -0.06927 & -0.54342 & 0.027861 & -0.06655 & 0.023931 \\
\hline New York2 & -0.59108 & -0.69198 & -0.6239 & -0.1626 & -0.04233 & 0.164476 \\
\hline New York1 & -0.39928 & 0.094831 & 0.309797 & 0.305994 & 0.079137 & -0.23789 \\
\hline New Jersey9 & -0.08228 & 0.053764 & 0.205561 & 0.107832 & 0.348556 & 0.332377 \\
\hline New Jersey8 & 0.145729 & 0.205536 & -0.00939 & 0.045185 & 0.10853 & 0.052792 \\
\hline New Jersey7 & 0.291612 & 0.552746 & 0.412828 & 0.213461 & 0.624899 & 0.515199 \\
\hline New Jersey6 & 0.217063 & 0.117759 & 0.120676 & 0.17374 & 0.402628 & 0.220784 \\
\hline New Jersey5 & -0.2044 & -0.16818 & -0.48515 & 0.381102 & 0.570934 & 0.612524 \\
\hline New Jersey4 & 0.102028 & 0.339569 & 0.282275 & 0.10447 & 0.008002 & 0.082873 \\
\hline New Jersey3 & -0.61737 & -0.83374 & -0.40891 & 0.415036 & 0.569583 & 0.581117 \\
\hline New Jersey2 & -0.06871 & 0.011789 & 0.351761 & 0.089031 & 0.353269 & 0.226332 \\
\hline New Jersey1 & -0.10345 & 0.105707 & -0.10639 & 0.419118 & 0.726764 & 0.608737 \\
\hline Delaware1 & -0.17877 & -0.4055 & -0.26207 & 0.003589 & -0.09073 & -0.30117 \\
\hline Maryland1 & 0.005773 & 0.073997 & 0.242193 & -0.02634 & 0.017682 & 0.150606 \\
\hline Virginia12 & -0.10359 & -0.16801 & -0.19339 & 0.029798 & 0.059715 & 0.055696 \\
\hline Virginia11 & -0.40403 & -0.14275 & 0.24763 & -0.02237 & 0.520963 & 0.141626 \\
\hline Virginia10 & -0.37967 & -0.34945 & 0.000728 & -0.02503 & 0.257716 & 0.571434 \\
\hline Virginia9 & -0.06196 & -0.00568 & -0.08664 & 0.145887 & 0.238378 & 0.164923 \\
\hline Virginia8 & -0.15521 & -0.36874 & -0.6393 & 0.45665 & 0.42626 & 0.501026 \\
\hline Virginia7 & -0.25557 & -0.74775 & -0.7111 & 0.088547 & 0.106359 & 0.61136 \\
\hline Virginia6 & 0.037561 & 0.120676 & 0.746808 & -0.26258 & -0.39069 & -0.68728 \\
\hline Virginia5 & -0.54848 & N/A & N/A & -0.94385 & $\mathrm{~N} / \mathrm{A}$ & N/A \\
\hline Virginia4 & -0.96205 & -0.66748 & N/A & 0.925424 & 0.857653 & N/A \\
\hline Virginia3 & 0.064669 & -0.21759 & N/A & 0.111884 & 0.363048 & $\mathrm{~N} / \mathrm{A}$ \\
\hline Virginia2 & 0.125624 & 0.759211 & 0.803326 & 0.02661 & 0.620772 & 0.891446 \\
\hline Virginia1 & 0.744398 & N/A & N/A & -0.01646 & N/A & $\mathrm{N} / \mathrm{A}$ \\
\hline $\begin{array}{c}\text { North Carolina } \\
\text { P96 }\end{array}$ & 0.144269 & -0.10529 & -0.00876 & -0.10541 & -0.18824 & -0.13276 \\
\hline $\begin{array}{c}\text { North Carolina } \\
\text { P92 }\end{array}$ & 0.349557 & -0.27417 & -0.31334 & 0.025203 & -0.28839 & -0.2133 \\
\hline $\begin{array}{c}\text { North Carolina } \\
\text { P91 }\end{array}$ & -0.25219 & N/A & $\mathrm{N} / \mathrm{A}$ & 0.145667 & $\mathrm{~N} / \mathrm{A}$ & $\mathrm{N} / \mathrm{A}$ \\
\hline $\begin{array}{c}\text { North Carolina } \\
\text { P90 }\end{array}$ & 0.250724 & 0.039114 & 0.142102 & 0.017522 & -0.01094 & 0.143771 \\
\hline $\begin{array}{c}\text { North Carolina } \\
\text { P89 }\end{array}$ & 0.021587 & 0.218485 & 0.102581 & -0.24125 & -0.01805 & -0.18751 \\
\hline
\end{tabular}




\begin{tabular}{|c|c|c|c|c|c|c|}
\hline $\begin{array}{c}\text { North Carolina } \\
\text { P88 }\end{array}$ & 0.079472 & 0.050025 & 0.04052 & -0.06983 & -0.06712 & -0.06532 \\
\hline $\begin{array}{c}\text { North Carolina } \\
\text { P87 }\end{array}$ & -0.19644 & 0.324325 & 0.550742 & 0.027631 & 0.254313 & 0.579232 \\
\hline $\begin{array}{c}\text { North Carolina } \\
\text { P85 }\end{array}$ & -0.37264 & -0.83128 & N/A & -0.51683 & -0.91692 & N/A \\
\hline $\begin{array}{c}\text { North Carolina } \\
\text { P84 }\end{array}$ & -0.0911 & 0.525982 & N/A & 0.124373 & 0.591191 & N/A \\
\hline $\begin{array}{c}\text { North Carolina } \\
\text { P83 }\end{array}$ & -0.01929 & -0.08488 & 0.122145 & -0.00162 & -0.25567 & -0.24168 \\
\hline $\begin{array}{c}\text { North Carolina } \\
\text { P81 }\end{array}$ & -0.30684 & -0.21183 & -0.34157 & -0.65238 & -0.33897 & 0.316539 \\
\hline $\begin{array}{c}\text { North Carolina } \\
\text { P80 }\end{array}$ & -0.21832 & 0.071481 & -0.06178 & 0.17744 & 0.422571 & -0.12204 \\
\hline $\begin{array}{c}\text { North Carolina } \\
\text { P78 }\end{array}$ & -0.56693 & -0.78673 & -0.70293 & -0.51285 & -0.69875 & -0.10446 \\
\hline $\begin{array}{c}\text { North Carolina } \\
\text { P76 }\end{array}$ & -0.09098 & 0.140232 & -0.14015 & 0.067391 & 0.501133 & 0.1847 \\
\hline $\begin{array}{c}\text { South Carolina } \\
\text { P68 }\end{array}$ & -0.10677 & -0.44164 & -0.68018 & -0.33971 & -0.81407 & -0.90549 \\
\hline Florida P19 & 0.025201 & 0.099415 & 0.279159 & 0.054233 & 0.095545 & 0.12083 \\
\hline Florida P18 & 0.124249 & -0.04477 & -0.13314 & -0.04349 & -0.37348 & -0.55988 \\
\hline Florida P17 & -0.03337 & 0.052037 & 0.01319 & -0.00258 & 0.040937 & 0.033951 \\
\hline Florida P16_2 & 0.093654 & 0.1549 & 0.255917 & 0.005374 & 0.006049 & -0.02489 \\
\hline Florida P16_1 & -0.09532 & -0.11464 & -0.05769 & -0.08013 & -0.09641 & -0.0637 \\
\hline Florida P15 & 0.021525 & 0.053018 & -0.02001 & 0.020112 & 0.024078 & 0.036264 \\
\hline Florida P10 & -0.16552 & 0.161041 & 0.271616 & -0.05879 & -0.13993 & -0.09773 \\
\hline Florida P9 & 0.087139 & -0.15064 & -0.21389 & 0.299981 & -0.01654 & 0.10858 \\
\hline Texas14 & -0.00358 & -0.12428 & -0.27463 & 0.035979 & 0.008918 & 0.000558 \\
\hline Texas13 & 0.050743 & 0.004555 & -0.04873 & 0.045255 & 0.016686 & -0.00247 \\
\hline Texas12 & -0.04612 & 0.135178 & 0.13365 & -0.04115 & -0.1909 & -0.575 \\
\hline Texas11 & -0.03796 & -0.37634 & -0.37393 & -0.04811 & 0.074985 & 0.071233 \\
\hline Texas10 & -0.07537 & -0.13733 & -0.20475 & -0.1033 & -0.07987 & -0.19432 \\
\hline Texas9 & -0.03402 & -0.0859 & -0.14875 & -0.00463 & 0.021958 & -0.03221 \\
\hline Texas8 & -0.11271 & 0.061099 & 0.044159 & -0.12668 & 0.029944 & 0.104228 \\
\hline Texas7 & -0.06834 & -0.17361 & -0.28095 & -0.10502 & -0.18407 & -0.25799 \\
\hline Texas6 & -0.19458 & -0.5778 & -0.71853 & -0.19394 & -0.54149 & -0.66695 \\
\hline Texas5 & -0.05542 & -0.25435 & -0.43196 & -0.00979 & 0.037675 & -0.00574 \\
\hline Texas4 & 0.009212 & -0.03978 & -0.05869 & -0.01434 & -0.06512 & -0.08189 \\
\hline Texas3 & 0.003582 & -0.06113 & -0.08572 & 0.003729 & 0.006362 & -0.01497 \\
\hline Texas2 & -0.04068 & -0.07482 & -0.09748 & -0.00601 & -0.01158 & 0.017724 \\
\hline Texas1 & -0.06139 & -0.58019 & -0.7515 & -0.13321 & -0.50223 & -0.63403 \\
\hline
\end{tabular}

C2019 American Geophysical Union. All rights reserved. 
Table 2. Total length of shorelines considered and percentage of total with significant correlations for each study region.

\begin{tabular}{|c|c|c|c|c|c|c|c|c|}
\hline \multirow{2}{*}{ Region } & \multirow{2}{*}{$\begin{array}{l}\text { Total } \\
\text { Length } \\
(\mathbf{k m})\end{array}$} & \multirow{2}{*}{$\begin{array}{c}\% \text { of shoreline } \\
\text { with significant } \\
\text { correlation }\end{array}$} & \multicolumn{3}{|c|}{ Short term shoreline change } & \multicolumn{3}{|c|}{ Long term shoreline change } \\
\hline & & & $1 \mathrm{~km}$ & $3 \mathrm{~km}$ & $5 \mathrm{~km}$ & $1 \mathrm{~km}$ & $3 \mathrm{~km}$ & $5 \mathrm{~km}$ \\
\hline \multirow{3}{*}{ Mid-Atlantic } & \multirow{3}{*}{487.6} & total & 48.6 & 55.2 & 54.4 & 50.6 & 68.3 & 70.0 \\
\hline & & positive & 10.1 & 19.3 & 29.1 & 46.4 & 52.1 & 52.2 \\
\hline & & negative & 38.4 & 35.8 & 25.3 & 4.3 & 16.1 & 17.9 \\
\hline \multirow{3}{*}{$\begin{array}{l}\text { North } \\
\text { Carolina }\end{array}$} & \multirow{3}{*}{264.9} & total & 85.4 & 67.1 & 16.6 & 59.4 & 56.1 & 48.9 \\
\hline & & positive & 67.9 & 10.0 & 4.6 & 0.0 & 13.0 & 7.7 \\
\hline & & negative & 17.5 & 57.1 & 12.1 & 59.4 & 43.1 & 41.3 \\
\hline \multirow{3}{*}{ Florida } & \multirow{3}{*}{277.9} & total & 61.1 & 73.1 & 47.4 & 5.9 & 56.3 & 17.1 \\
\hline & & positive & 21.8 & 41.5 & 41.5 & 5.9 & 6.1 & 6.1 \\
\hline & & negative & 39.2 & 31.6 & 5.9 & 0.0 & 50.2 & 11.0 \\
\hline \multirow{3}{*}{ Texas } & \multirow{3}{*}{575.1} & total & 15.0 & 63.7 & 90.2 & 24.5 & 14.0 & 14.0 \\
\hline & & positive & 0.0 & 3.8 & 3.8 & 0.0 & 0.0 & 4.8 \\
\hline & & negative & 15.0 & 59.9 & 86.4 & 24.5 & 14.0 & 9.2 \\
\hline
\end{tabular}




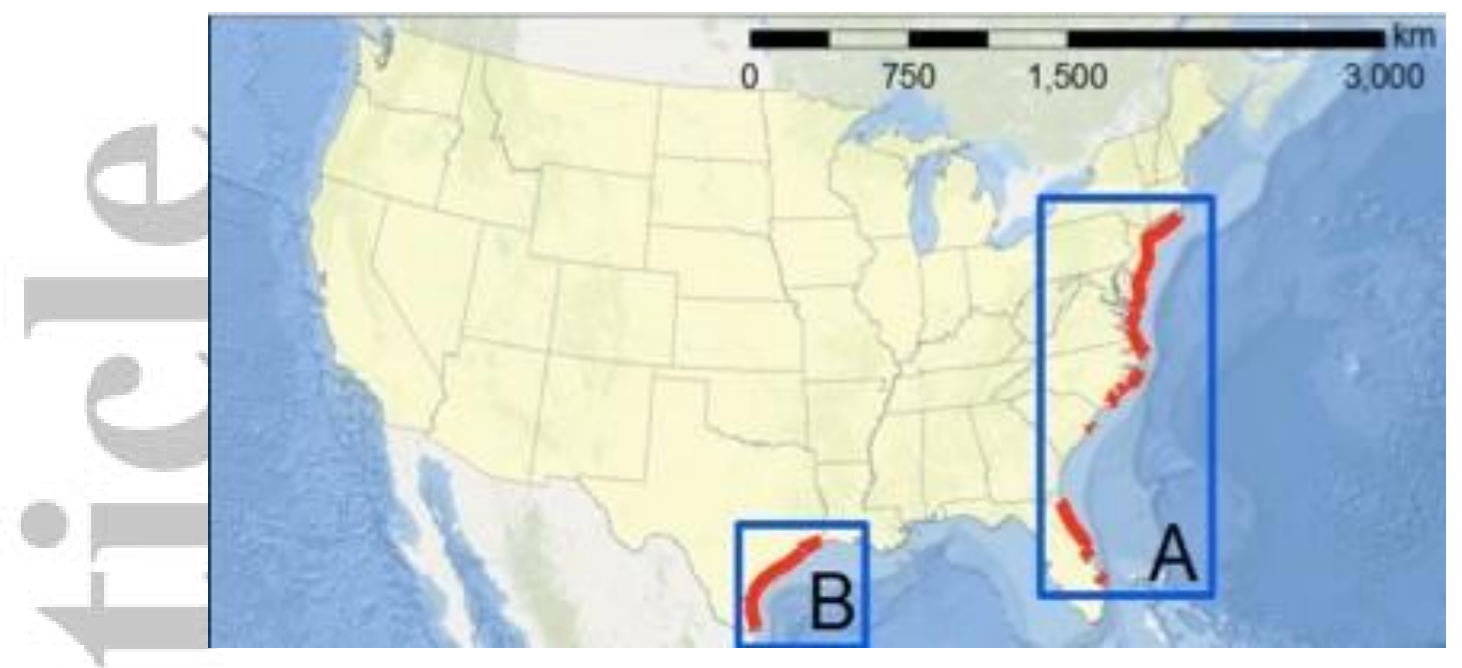

Figure 1. The extent of the shorelines on the A) Atlantic and B) Gulf coasts considered in our study.

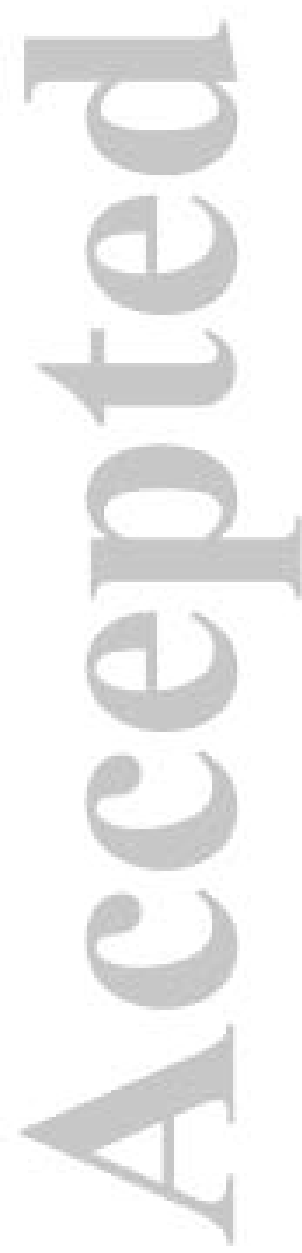



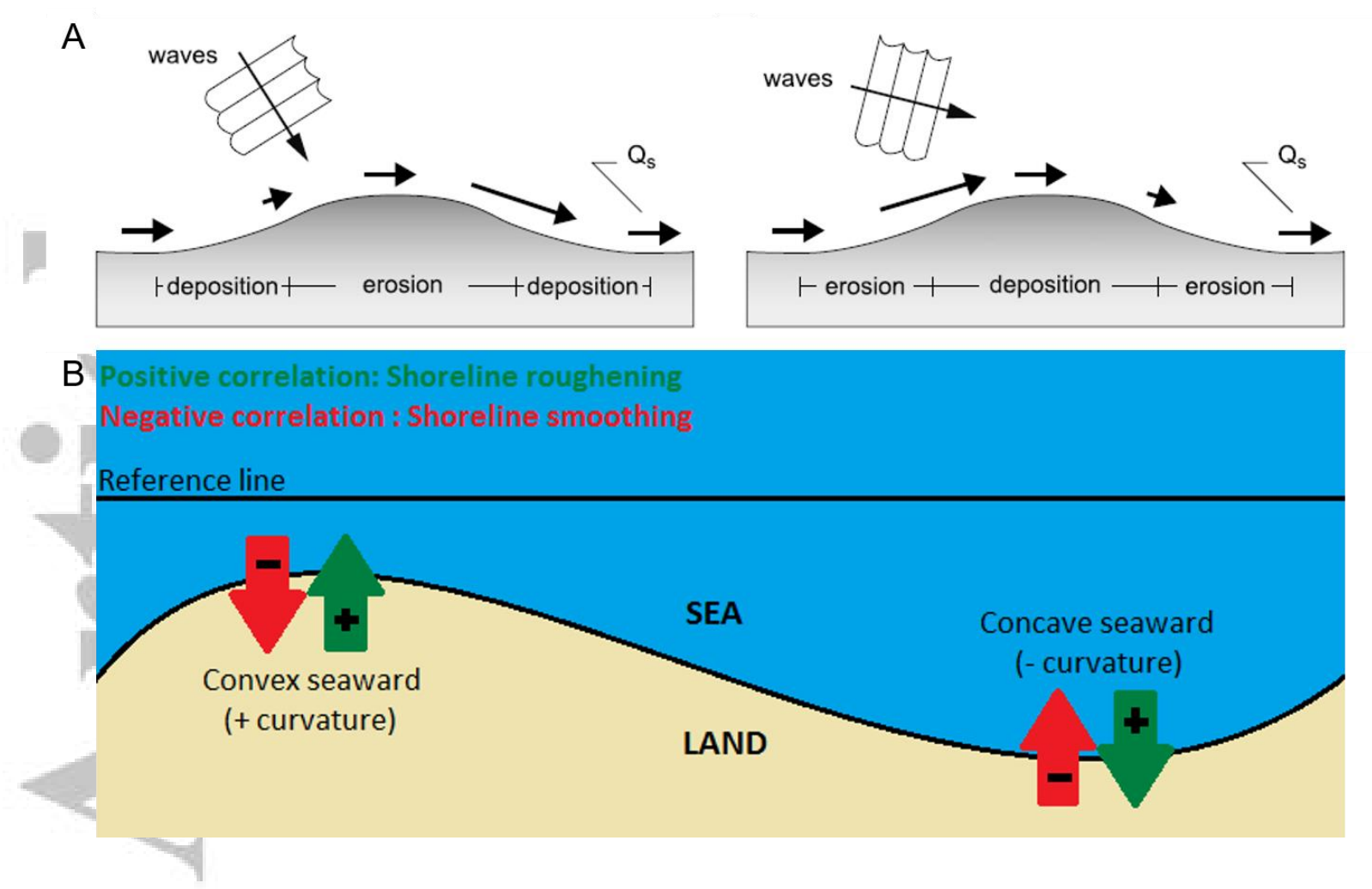

Figure 2. a) A schematic of gradients in alongshore currents created by shoreline curvature. Reproduced from Ashton and Murray (2006a). b) Sign conventions used in this analysis. Convex (concave) seaward curvature is defined as positive (negative). Accretion (erosion) is positive (negative) shoreline change. A positive (negative) correlation represents roughening (smoothing) of the shoreline. 


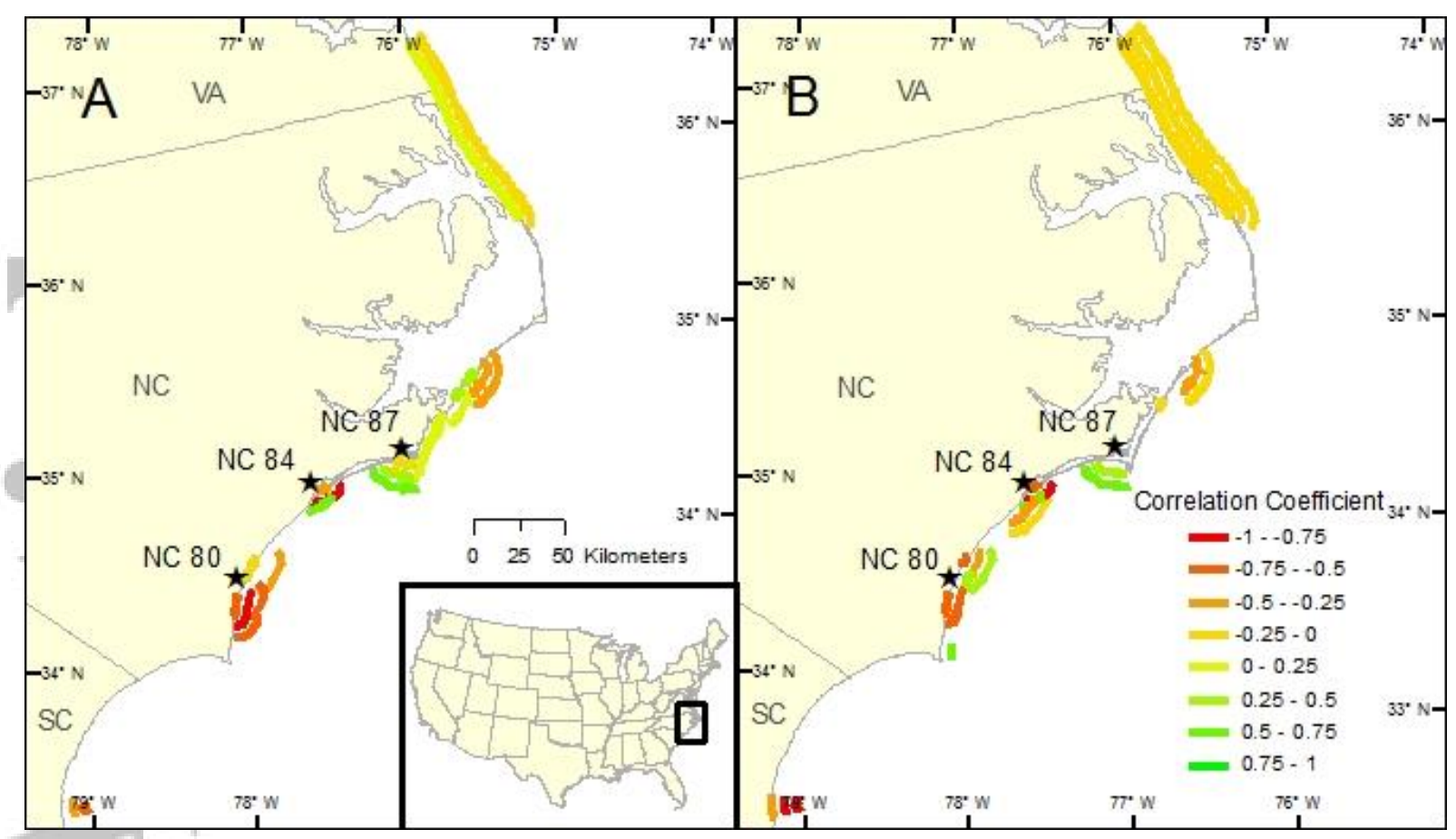

Figure 3. Map showing the significant correlation coefficients between shoreline curvature and shoreline change for the North and South Carolina coasts. A) Correlations between shoreline curvature and short-term (decadal) shoreline change. B) Correlations between shoreline curvature and long-term (century-scale) shoreline change. For both timescales, data is plotted in the following order: moving away from the coast, $1 \mathrm{~km}, 3 \mathrm{~km}$, and $5 \mathrm{~km}$ smoothing. Stars mark shoreline sections discussed in detail in the text; NC 87 is Shackleford Banks, NC 84 is Browns Island, and NC 80 is Figure Eight Island. 


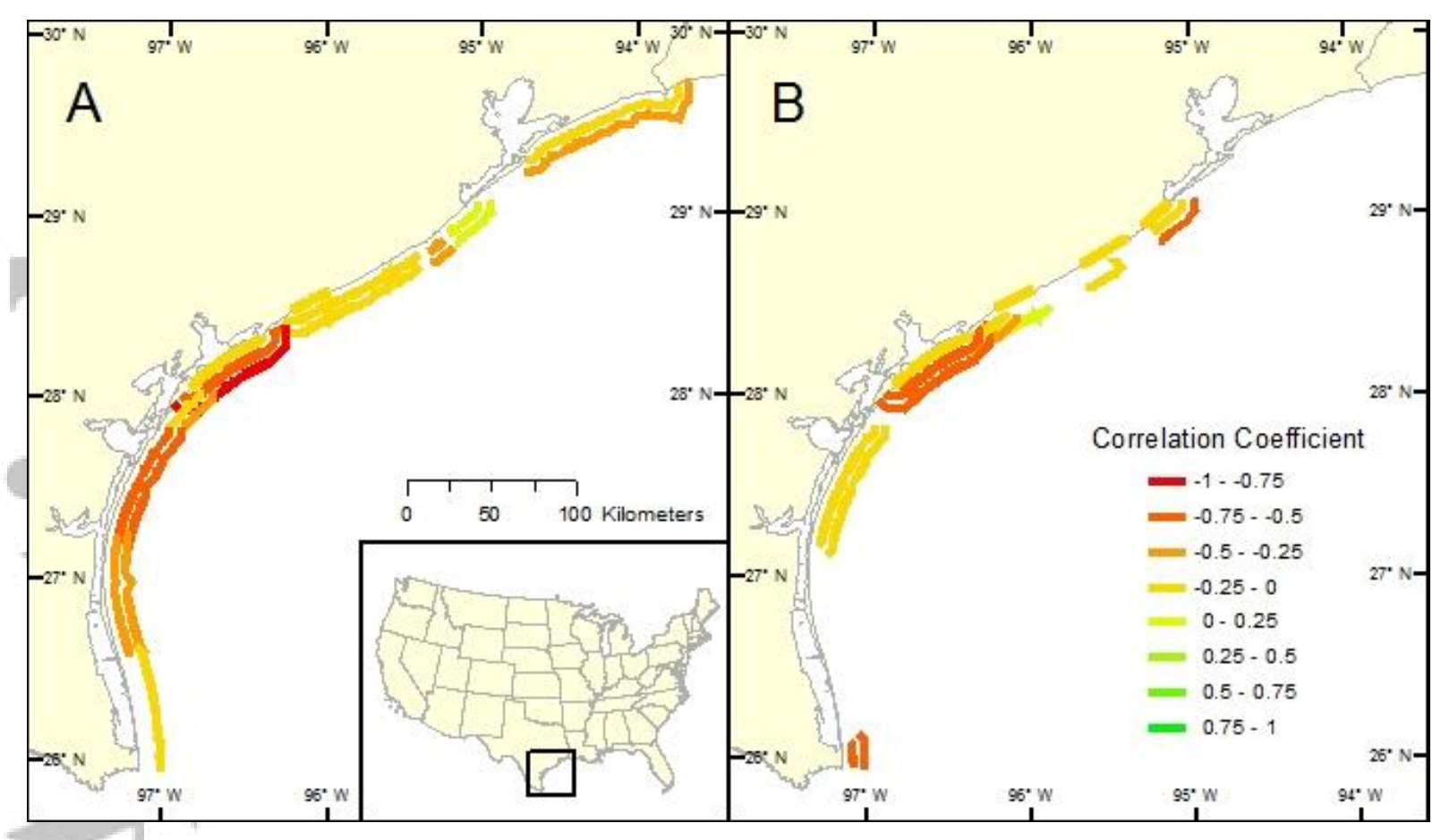

Figure 4. Map showing the significant correlation coefficients between shoreline curvature and shoreline change for the Texas Gulf coast. A) Correlations between shoreline curvature and short-term (decadal) shoreline change. B) Correlations between shoreline curvature and long-term (century-scale) shoreline change. For both timescales, data is plotted in the following order: moving away from the coast, $1 \mathrm{~km}, 3 \mathrm{~km}$, and $5 \mathrm{~km}$ smoothing. Stars mark shoreline sections discussed in detail in the text. 


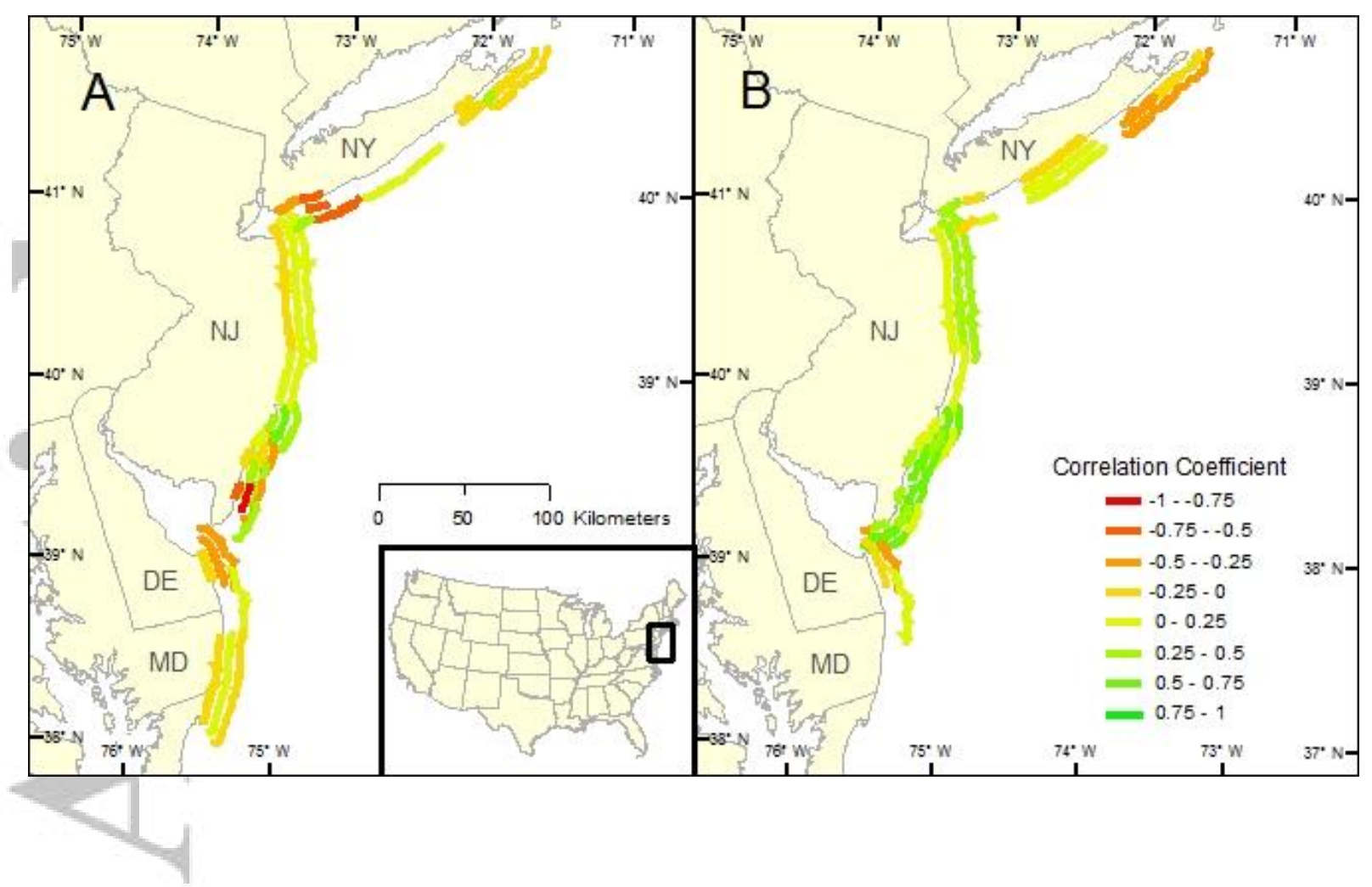

Figure 5. Map showing the significant correlation coefficients between shoreline curvature and shoreline change for the Mid-Atlantic coast (from New York to Assateague Island, Virginia). A) Correlations between shoreline curvature and short-term (decadal) shoreline change. B) Correlations between shoreline curvature and long-term (century-scale) shoreline change. For both timescales, data is plotted in the following order: moving away from the coast, $1 \mathrm{~km}, 3 \mathrm{~km}$, and $5 \mathrm{~km}$ smoothing. Stars mark shoreline sections discussed in detail in the text; NY 4 is Fire Island. 


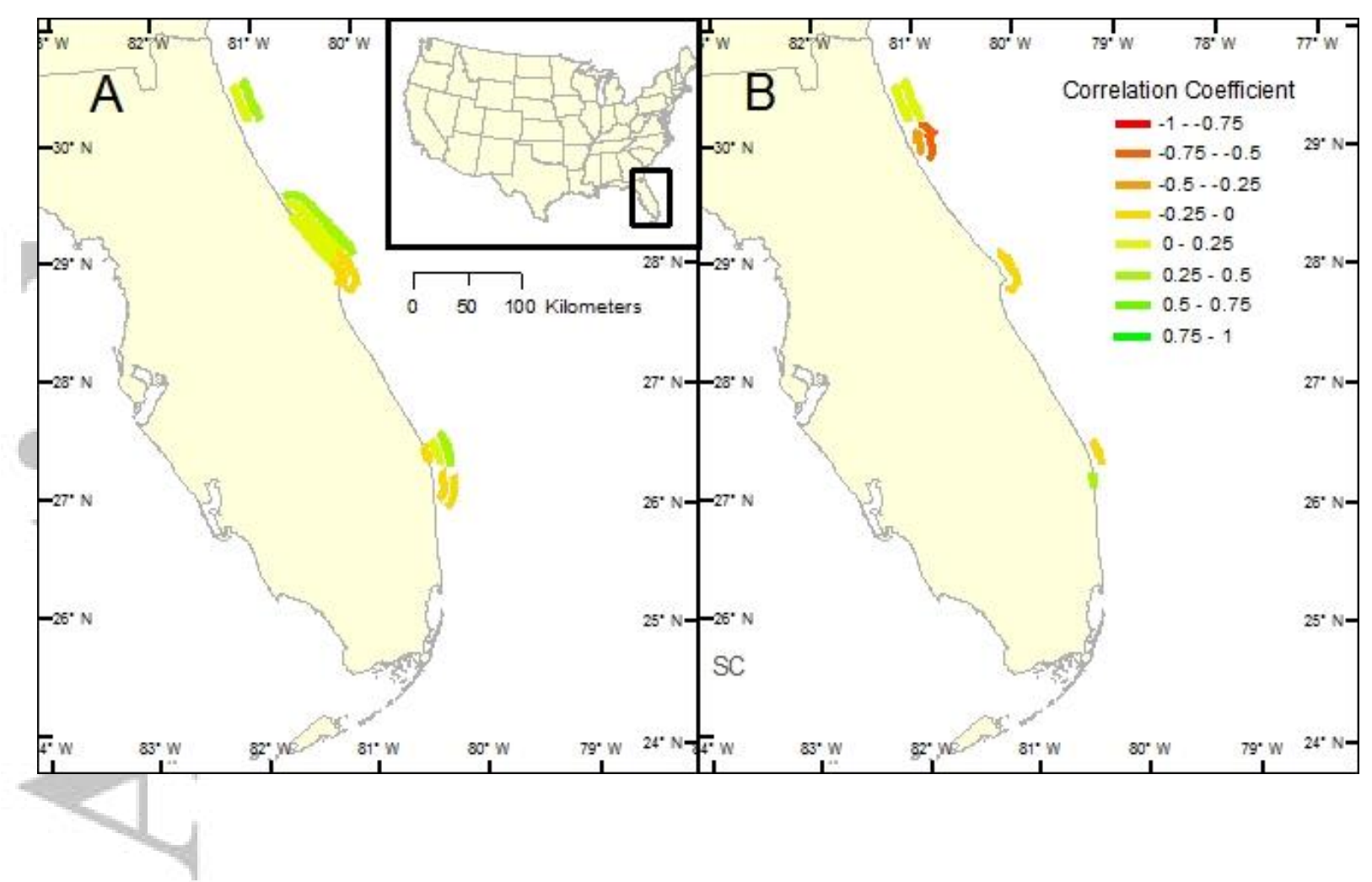

Figure 6. Map showing the significant correlation coefficients between shoreline curvature and shoreline change for the Atlantic Coast of Florida. A) Correlations between shoreline curvature and short-term (decadal) shoreline change. B) Correlations between shoreline curvature and long-term (century-scale) shoreline change. For both timescales, data is plotted in the following order: moving away from the coast, $1 \mathrm{~km}, 3 \mathrm{~km}$, and $5 \mathrm{~km}$ smoothing. 


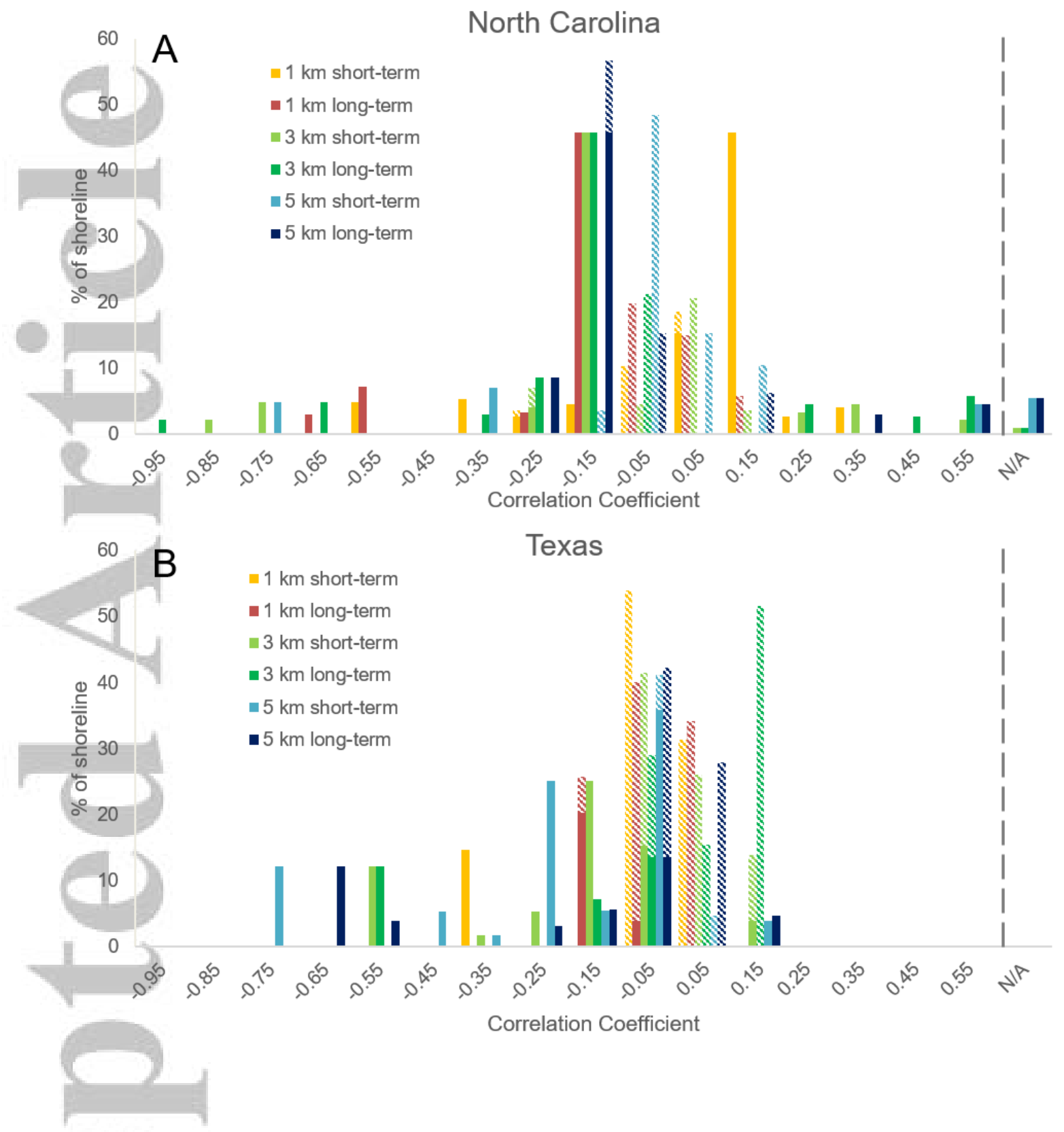

Figure 7. Distribution of correlations in terms of shoreline length for A) North Carolina and B) Texas. Solid boxes represent significant correlations, and shaded boxes insignificant. Percent of shoreline refers to the total shoreline considered, not total shoreline existing. 